\title{
MADD Gene
}

National Cancer Institute

\section{Source}

National Cancer Institute. MADD Gene. NCI Thesaurus. Code C24565.

This proto-oncogene is involved in the regulation of apoptosis and propagates cell death via signal transduction. 